disease in three of the mice extending from the stomach to the rectum. In some situations even the muscular layer was invaded by the specific microorganism, although the majority were found in the apices of the villi. The bacteria were grown on F. W. Twort's Myco. phlei egg medium or acclimatized to grow on ordinary glycerine-beef broth, although admittedly it would probably have been better to use naturally infected bovine gut. It was easier to infect by injection than by feeding, but by the latter method infection of the mesenteric glands was not at all difficult, although, of course, this does not mean that intestinal disease would have followed had the animals been allowed to survive.

Portslade Research Laboratories, C. C. Twort.

South Street, Portslade,

Sussex.

NatuRE, 152, 250 (1943).

2 Vet. News, Jan. 24, 1914

IN the corrected proof of my article, which unfortunately, owing to my absence on leave, did not reach the printers until the article was in press, I had altered the phrase to which $\mathrm{Mr}$. Twort objects to read, "it was generally accepted that laboratory animals could not be infected with Myco. leproe or with Myco. johnei". This correction was made in the reprints. In my original paper ${ }^{1}$, I gave a summary of 'Twort's work but also referred to subsequent experiments which had led workers "generally to accept that laboratory animals could not be infected with Myco. johnei". Owing to the almost complete failure of the subsequent experiments, it has not been possible to study Johne's disease in laboratory animals. It is hoped that by the use of very young animals this will now be possible.

John Francis.

J. Comp. Path., 58, 140 (1943).

\section{Propagation of Potatoes}

IT is interesting in view of the recent correspondence $^{1,2}$ on this subject to recall that a century ago the planting of whole tubers was by no means the only method employed for propagating the potato. Loudon ("Encyclopaedia of Agriculture", 1844) lists the use of small cuttings, sprouts, shoots, eyes, and buds, as methods of propagation, and in "Encyclopaedia of Gardening" these and other methods are described. The following notes are based on descriptions given in the 1871 edition of "The Encyclopaedia of Gardening", although, so far as can be judged from the preface, they are likely to be identical with descriptions given in the earlier (1834) edition.

Cuttings were made of young stalks or branches, $5-6$ in. in length, in May or June and struck in showery weather in the open or under a hand-glass or in pots. Layers were made in June or July whon the potato stalks were 1-2 ft. long, and after layering, these shoots, according to Louden, emit roots at every leaf and produce full-grown potatoes the same year. Suckers may be removed in June, with a few roots attached, and planted carefully when, like layers, they will produce a late crop of tubers.

In seasons of scarcity the sprouts generally found on store potatoes in spring may, when carefully planted in loose well-prepared soil, be made to yield a crop. Propagation by portions of tuber is, accord- ing to Louden, the only method fit for general use. He writes: "In making the sets or sections reject the extremes or watery end of the tuber as apt to run too much to haulm, and having the eyes small and in a cluster. Reject also the root or dry end as more likely to be tardy in growth and as according to some producing the curl. Then divide the middle of the potato so as to have not more than one good eye in each set. Where the potato scoop (described and figured in 'Encyclopaedia of Agriculture') is used, take care to apply it so that the bud or eye may be in the centre of each set which this instrument produces of a semi-globular form. The larger the portion of tuber left to each eye, so much the greater will be the progress of the young plant. The scoop is only to be used in seasons of scarcity when the portion of tuber saved by it may be used for soups for the poor or for feeding cattle."

Botany Department,

The University,

Manchester. Sept. 29.

${ }^{1}$ Polunin, N., Nature, 151, 421 (1943).

${ }^{2}$ Bates, G. H., NATURE, 152, 135 (1943).

\section{Future of Technical Colleges}

THE attention of the Council of the Association of Technical Institutions has been directed to the letter on the above subject by Dr. H. Lowery.

The Council is much concerned at some of the statements which are made in that letter. These statements give a very inaccurate picture of the work done by the technical colleges at the present time, and it is doubtful whether in the majority of cases they would ever have been true. In those technical colleges where degree courses are undertaken they are certainly not in any way of a makeshift character, and it would be untrue to say that they have grown out of a makeshift system. In many of the larger technical colleges the staff and laboratory equipment compare most favourably with those of the universities, and not only are the numbers of students comparable, but also the results obtained are academically excellent. The numbers of students taking honours degree courses of the University of London in the technical colleges of the country are quite comparable with those in the internal colleges of the University itself, and it must be remembered that the term 'external' has now quite changed in significance, since the technical colleges working for London degrees are inspected by representatives of the universities and only offer degree courses after full approval by the University has been given.

There is much in Dr. Lowery's letter with which we should very heartily concur, but there would appear to be no useful purpose served by deprecating the outstandingly excellent work on the degree side which many technical colleges have undertaken for some time now, and it is particularly unfortunate that in submitting the evidence to support his case, he should have used statements so far from the truth.

H. Schofierd.

(Hon. Secretary.)

H. Garrat'T.

(Chairman of the Council.)

Association of 'Technical Institutions,

Loughborough College.

Oet. 2 . 